\title{
Aquilaria malaccensis as a Green Corrosion Inhibitor for Mild Steel in HCl Solution
}

\author{
Helen Lee Yun Sin ${ }^{1,2}$, Minoru Umeda ${ }^{1}$, Sayoko Shironita ${ }^{1}$, Afidah Abdul Rahim ${ }^{2, *}$, Bahruddin Saad ${ }^{2}$ \\ ${ }^{1}$ Department of Materials Science and Technology, Nagaoka University of Technology, 1603-1 \\ Kamitomioka, 940-2188 Nagaoka, Niigata, Japan \\ ${ }^{2}$ School of Chemical Sciences, Universiti Sains Malaysia, 11800 Pulau Pinang. Malaysia \\ *E-mail: afidah@usm.my
}

doi: $10.20964 / 2016.09 .54$

Received: 15 April 2016 / Accepted: 11 July 2016 / Published: 7 August 2016

The methanolic extract from the leaf of Aquilaria malaccensis was confirmed to inhibit the corrosion of mild steel in $1 \mathrm{~mol} \mathrm{dm}^{-3} \mathrm{HCl}$ based on gravimetric and electrochemical methods, and the leaf extract was found to inhibit corrosion by as much as $94.49 \%$ at the concentration of $1500 \mathrm{ppm}$. The leaf extract acted as a mixed-type, but predominantly cathodic inhibitor for the potentiodynamic polarization measurement. The adsorption of the leaf extract on the surface of mild steel was by a mixed-type, but predominantly physisorption process, fitting the best into the Langmuir adsorption isotherm model. The surface morphology analysis revealed a less damaged surface when the leaf extract was added.

Keywords: Aquilaria malaccensis, corrosion inhibitor, mild steel, $\mathrm{HCl}$

\section{FULL TEXT}

(C) 2016 The Authors. Published by ESG (www.electrochemsci.org). This article is an open access article distributed under the terms and conditions of the Creative Commons Attribution license (http://creativecommons.org/licenses/by/4.0/). 